
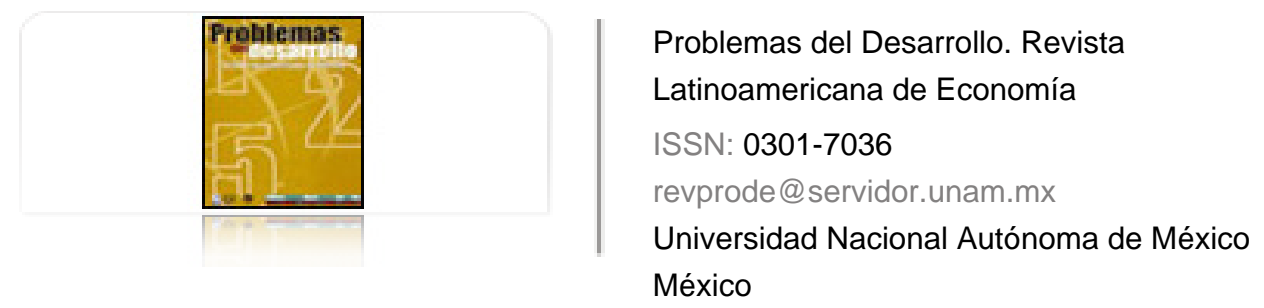

Hira, Anil

The FTAA as a Three-level Bargaining Game

Problemas del Desarrollo. Revista Latinoamericana de Economía, vol. 34, núm. 133, 2003, pp. 157-

179

Universidad Nacional Autónoma de México

Distrito Federal, México

Available in: http://www.redalyc.org/articulo.oa?id=11825949014

How to cite

Complete issue

- More information about this article

Journal's homepage in redalyc.org

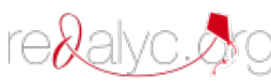

Scientific Information System Network of Scientific Journals from Latin America, the Caribbean, Spain and Portugal Non-profit academic project, developed under the open access initiative 


\title{
The ftaA as a Three-Level Bargaining Game*
}

\begin{abstract}
Anil Hira**
Fecha de recepción: 17 de enero de 2003. Fecha de autorización: 28 de octubre de 2003 .

Abstract

This paper applies Putnam's (1993) seminal work on negotiations as a two level game, to the Free Trade Area of the Americas (FTAA) negotiations process. The paper compares the domestic ratification processes with the existing web of regional and bilateral trade agreements for insights into the relative bargaining strength and key issues for the most important economies in the hemisphere: the United States, Canada, Brazil, and Mexico. This paper delivers important insights into how the existing international and domestic legal and political context will affect the dynamic shape of FTAA negotiations, with the aim of finding strategies by which Latin American countries (LACS) can maximize their bargaining power.
\end{abstract}

Key words: integration, FTAA, trade, international bargaining, sectoral analysis.

\section{Resumen}

Este texto aplica el trabajo seminal de Putnam (1993) sobre las negociaciones, entendidas éstas como un juego de dos niveles, al proceso de negociación del Área de Libre Comercio de las Américas (ALCA). En este trabajo se comparan los procesos nacionales de ratificación y la amplia red de acuerdos comerciales regionales y bilaterales, con el fin de encontrar fortalezas relativas y temas clave para las economías más importantes del continente: Estados Unidos, Canadá, Brasil y México. El trabajo resulta sugerente en cuanto a cómo los contextos internacional y nacional, legal y político, afectarán la forma en qué se realicen las negociaciones del $A L C A$, de manera que se puedan encontrar estrategias para que los países de América Latina (PAL) maximicen su poder de negociación.

Palabras clave: integración, ALCA, comercio, negociación internacional, análisis sectorial.

* This paper was first presented at the Inter American Development Bank, CEREs (Uruguay) and Latin American and Caribbean Economic Association sponsored Regional Integration Network meeting in Punta del Este, Dec. 2002, at the March 2003 LASA meeting in Dallas, and at the May, 2003 Simon Fraser University Center for Global Political Economy Conference with the University of Hull (Canada), and is part of a long-term study of the FTAA. I would like to thank my sfu class for their discussions. I would also like to thank Andrew Powell, Jeffrey Hallerberg, Chris Kukucha, and Robert Devlin for their comments, and my colleague, Ted Cohn, for invaluable feedback. I am dedicating this article to my great colleague and friend Gerardo Otero.

** Department of Political Science \& Latin American Studies Simon Fraser university burnaby, Bc, Canada, V5A1S6. Correo electrónico: ahira@stu.ca 


\section{Résumé}

Ce texte met en application le travail de base de Putman (1993) sur les négociations —celles-ci étant comprises comme un jeu à deux niveaux - par rapport au processus de négociations de la Zone de Libre Echange des Amériques (ZLEA). Dans ces travaux, on compare les processus nationaux de ratification et l'ample réseau des accords commerciaux régionaux et bilatéraux, dans le but de trouver des renforcements y relatifs et des thèmes clés pour les économies les plus importantes du continent: les Etats-Unis, le Canada, le Brésil et le Mexique. Ceci reste une suggestion quant à la façon dont les contextes international et national, légal et politique, affecteront celle dont se réaliseront les négociations de l'ALCA, de sorte que l'on puisse trouver des stratégies pour que les pays d'Amérique latine (PAL) optimisent leur pouvoir de négociation. Mots-cléfs: intégration, ZLEA, commerce, négociation internationale, analyse sectorielle.

\section{Resumo}

Este artigo aplica o trabalho seminal de Putman (1993) sobre as negociações, entendidas estas como um jogo de dois níveis, ao processo de negociação da Área de Livre Comércio das Américas (ALCA). No trabalho comparam-se os processos nacionais de ratificação e a ampla rede de acordos comerciais regionais e bilaterais, para encontrar as forças relativas e os temas chaves para as economias mais importantes do continente: Estados Unidos, Canadá, Brasil e México. $O$ trabalho nos sugere como os contextos internacional e nacional, legal e político, afetarão a forma em que se realizam as negociações da ALCA de maneira a poder encontrar estratégias para que os países da América Latina (PAL) maximizem o seu poder de negociação.

Palavras chave: integração, ALCA, comércio, negociação internacional, análise setorial. 


\section{Introduction}

Much of the criticism directed at a possible Free Trade Agreement of the Americas (FTAA) pictures a behemoth U.S. demanding conditions from other countries of the hemisphere in return for a limited increase in access to the world's largest market (Grinspun and Cameron, 1994). The reasons for this fear have to do with regional asymmetries:

Table 1

Largest Countries in the FTAA Region, Japan, and the E.U.

\begin{tabular}{lrlr}
\hline & GDP & & Population \\
\hline Japan & 4841.6 & Japan & 126.9 \\
European Union & 7894.5 & European Union & 378 \\
United States & 9837.4 & United States & 281.6 \\
Canada & 687.9 & Brazil & 170.4 \\
Brazil & 595.5 & Mexico & 98.0 \\
Mexico & 574.5 & Colombia & 42.3 \\
Argentina & 285.0 & Argentina & 37.0 \\
Venezuela & 121.3 & Canada & 30.8 \\
Colombia & 81.3 & Peru & 25.7 \\
Chile & 70.5 & Venezuela & 24.2 \\
Peru & 53.5 & Chile & 15.2 \\
Uruguay & 19.7 & Ecuador & 12.6 \\
Costa Rica & 15.9 & Cuba & 11.2 \\
Ecuador & 13.6 & Bolivia & 8.3 \\
Bolivia & 8.3 & Paraguay & 5.5 \\
Paraguay & 7.5 & Nicaragua & 5.1 \\
Nicaragua & 2.4 & & \\
\hline
\end{tabular}

Notes: Units are \$billions, current and millions.

Source: World Bank, wDI; E.U.; year $=2000$.

We can also analyze the potential for FTAA trade gains by creating a table showing the existing and potential size of growth for the FTAA. By looking at the balance of trade, we can examine the potential gains from trade for individual countries.

Table 2 demonstrates a number of important facts about the FTAA. The first is the wellknown fact that the U.S. dwarfs all other economies in the region, however, we can add that there are additional tiers in terms of the overall size of the economies and the level of trade in the region. Despite the fact that Brazil's economy is on a par (in terms of GDP) with Mexico and Canada, Brazil depends much less on trade. Secondly, we see that the U.S. 
Table 2

Potential Size and Growth of FTAA Market

\begin{tabular}{|c|c|c|c|c|c|c|c|}
\hline Country & $\begin{array}{l}\text { Total Trade } \\
\qquad(X+M)\end{array}$ & $\begin{array}{c}\text { Trade } \\
\text { Balance }\end{array}$ & $X w / F T A A$ & $M w / F T A A$ & $\begin{array}{c}\text { Total Trade } \\
\text { with FTAA }\end{array}$ & $\begin{array}{c}\text { \% of Tot. } \\
\text { Trade } \\
\text { w/FTAA }\end{array}$ & $\begin{array}{c}\text { Balance } \\
\text { w/FTAA }\end{array}$ \\
\hline rge & $46,918,234$ & $6,289,780$ & 1 & 48 & 789 & $56.1 \%$ & 907 \\
\hline razil & 107,4 & -1 & 23 , & 31 & 578 & $45.8 \%$ & 4,485 \\
\hline Canada & $480,263,280$ & $39,532,116$ & $155,184,480$ & $230,965,128$ & $386,149,608$ & $80.4 \%$ & $75,780,648$ \\
\hline Mexico & $278,764,071$ & -5359283 & $127,332,042$ & $111,750,555$ & $239,082,597$ & $85.8 \%$ & $15,581,487$ \\
\hline U.S. & $1,842,764,963$ & $461,624,937$ & $408,156,781$ & $300,658,687$ & $708,815,468$ & $38.5 \%$ & $-107,498,094$ \\
\hline Venezuela & $7,975,277$ & $2,210,373$ & $1,747,671$ & $3,924,395$ & $5,672,066$ & $71.1 \%$ & $2,176,724$ \\
\hline
\end{tabular}

Notes: All values US\$1000s; all years 2001 exc. 2000 for US, 1999 for Mexico.

Source: Author Calculations from Inter-American Development Bank

Table 3

Present Destination of Exports for Largest fTAA Economies

\begin{tabular}{lrcl}
\hline Country & E.U. & U.S. and Canada & Japan \\
\hline Argentina & 16 & 11 & 1 \\
Brazil & 25 & 25 & 4 \\
Canada & 4 & 88 & 2 \\
Mexico & 4 & 87 & 1 \\
United States & 22 & 22 & 8 \\
Venezuela & 6 & 45 & 1 \\
\hline
\end{tabular}

Source: Author calculations from UNCTAD, Exports for 2001.

has a huge trade imbalance, with about a quarter of the deficit coming from the FTAA region. Thirdly, we see that Canada, Venezuela, and Mexico are already extremely concentrated in the Western Hemisphere in terms of trade. Table 3 reinforces further the fact that Brazil and Argentina, like the U.S., are much more oriented towards the European Union than the other countries in the hemisphere, and points to the fact that the U.S. is, in fact, the market for most FTAA regional trade.

This information suggests that, notwithstanding the possibilities for absolute gains in the volume of trade, the principal gains from an FTAA would be to increase trade between the U.S. and South American countries, and to a lesser extent, to increase trade among the LACs themselves. Moreover, domestic structural problems, beyond our scope here, such as land and income inequality and demographic pressures, add to the weaker bargaining position and greater obstacles to consensus faced by developing countries. In short, then, the U.S. would seem to hold most of the cards.

However, this analysis would miss a much wider picture of the true scenario for the FTAA negotiations. A proper analysis should consider, for example, that FTAA negotiations occur among partners with different negotiating organizations and procedures; among 
negotiators representing diverse and sometimes conflicting domestic interests; and within a web of pre-existing multilateral and bilateral agreements both within the region and between regional countries and extra-regional partners. We explore these complications in the following sections.

\section{Putnam's Two Level Bargaining Game}

Robert Putnam's classic 1988 article is the foundation of international bargaining theory. At the heart of the theory is the idea that international negotiators must satisfy diverse sets of domestic interests while at the same time pushing forward their view of the national interest in light of what is available to other negotiators. Putnam terms win sets the various stances that a negotiator can adopt and still win domestic ratification.

This implies a secondary level of complexity, namely that the knowledge of negotiating partners' win sets can be used as strategic information. Thus, a negotiator with a limited win set can claim to his/her negotiating partners that the negotiator really has little room to compromise. In a sense, therefore, the negotiator naturally has an interest in exaggerating the tightness of the win set. Obviously, win sets are dynamic, and subject not only to deception, but also to limited information, biases, and the perceptions of the decisionmaker in terms of the strategic context at international and national levels. Moreover, the decision-maker can also wield the veto axe, i.e. he/she can claim that certain issues are outside his/her win set and so unacceptable. Obviously, this is a very risky tool, because it could lead to the failure of the negotiations, if fellow negotiators take the threat at face value, or decide to play chicken with a similar threat.

Putnam's model admittedly misses potentially important factors. For example, Allison's classic article on bureaucratic decision-making during the Cuban missile crisis points to the importance of understanding public sector decision-making including political and national interest cost-benefit analyses, ministerial and sub-ministerial bargaining, and the importance of the sequence and characteristics of the decision-making process. Putnam's framework, in combination with a few concepts from international regime theory, such as issue linkage and side payments, can provide a powerful view of the context of the negotiations. Issue linkage involves both quid pro quo, or concessions, on different issues in order to reach an agreement. Issue linkage can also be thought of as the ways to create a winning coalition through an agreed-upon platform amongst differing interests. The concentration of issues could have important implications in terms of how bargaining occurs on the intra- and inter-sectoral level. Side payments are payments to losers in bargaining, as a form of compensation. These concepts can apply to bargaining at both the international and the domestic level. Obviously, we cannot predict the exact bargains states will make with each other or with domestic interest groups, since this can only be done in hindsight, as has been the case with post hoc NAFTA analyses. Similarly, just because we 
can lay out the maximum gains that a state could potentially negotiate, the state may not act upon them. It may lack negotiating skill or domestic unity (or other states could co-opt domestic opposition through side-payments) — but this is no different than firms not maximizing profit and/or market share or consumers not maximizing utility. We shall analyze the contours of an FTAA negotiation via the three levels: the multilateral and regional; the bilateral; and the national. We focus on the largest economies in the hemisphere, namely, Canada, the U.S., Brazil, and Mexico in order to illustrate the usefulness of our analytical framework.

\section{Multilateral, Regional, and Bilateral Analysis}

Existing multilateral, bilateral, and sub-regional agreements such as NAFTA and MERCOSUR have to be harmonized with an FTAA. Multi- and sub-regional bargaining constitutes a third and possibly fourth level of the strategic game that Putnam describes (Avery, 1993). In particular, the FTAA, like NAFTA, can be seen in part as a response to the success of the E.U. in creating a viable trading bloc with high external tariffs. With the recent E.U. expansion eastward, the U.S. has all the more reason to create a rival bloc. The FTAA negotiations should therefore be seen as a sub-game within the negotiating process of the Doha Round. Any concessions or victories the U.S. makes in an FTAA process must be seen as moves in its negotiations with the E.U. and, to a lesser extent (due to the closed nature and smaller size of its market), Japan. Moreover, developing countries have never been able to create a unified bloc for negotiating on a multilateral level, despite various formal (e.g., the NIEO) and informal attempts. The basic fact remains that most developing countries are competing against each other for access to First World markets. As Raymond F. Hopkins (1993) points out in regard to agriculture, developing countries have been largely ineffectual on the multilateral level for a number of reasons. There is disunity and variety among the developing countries, which makes negotiating as a bloc difficult. Furthermore, because most developing countries rely heavily on trade taxes as a major source of revenue, they are reluctant to move towards liberalization in some sectors, such as agriculture. Most developing countries, with their limited markets, also have limited concessions to offer developed countries. They call for differential treatment for key sectors, given their level of development. Last but not least, developing governments have limited capacity not only in negotiations on the multilateral level, but also on the domestic level, such as finding compensatory means by which to offer side payments to losers in liberalization. The North-South split on a possible quid pro quo between agriculture and services, investment, and intellectual property rights, which ended the Seattle wTO Ministerial session, persisted in the Doha Round, culminating in the failure of the Cancun Summit.

On a regional level, serious questions can be raised about the possibilities that either NAFTA or the MERCOSUR could negotiate as blocs. Obviously, the U.S. will negotiate on its 
own in an FTAA, rather than with Canada and Mexico. Moreover, we should point out that Canada and Mexico have vested interests in delaying or otherwise reducing liberalization concessions that would reduce its privileged access to the U.S. market. In practice, the main dynamic of the FTAA talks has been a rivalry between the U.S. and Brazil. The MERCOSUR agreement has stagnated more or less since 1995, when the Argentine economy began showing signs of weakness that culminated in its current financial crisis. Argentina and more recently Uruguay have flirted with the idea of a separate agreement with the U.S., although both make assurances that any bilateral agreement would be MERCOSUR-friendly. Similarly, the proposed South American Free Trade Area (SAFTA), championed by Castro, Chavez, and Lula, has not really emerged as an alternative. Nor have the various other alternatives, such as the Central American, Caribbean, and Andean Pact free trade areas, developed into anything resembling independent foreign policy making regional institutions.

A more interesting question is whether the E.U., the most important trading partner for the Southern Cone countries, could provide an alternative market to the U.S., thus creating leverage within an FTAA. Clearly, to the extent that the E.U. can create a regional wedge within the hemisphere, it can strengthen its negotiating position on the multilateral level. Although the E.U. has been successful in creating recent bilateral agreements with Chile and Mexico, the agreements are relatively limited. Agriculture is also the main sticking point in talks between MERCOSUR and the E.U. Interestingly enough, then, the E.U.'s policy on agriculture at the multilateral level pushes potential allies back towards the U.S. position. Given the E.U.'s apparent priorities towards Eastern Europe, and, the Lomé countries, it is unlikely to concede on agriculture to Latin America.

In sum, we argue that existing regional and sub-regional agreements will still work ultimately through the national lens. Sub-regional groupings such as MERCOSUR, or bilateral agreements such as Mexico-Brazil, could aid the process of building together loose sub-regional coalitions that could then increase their leverage vis-à-vis the U.S. or other partners. ${ }^{1}$ The middle level players, such as Venezuela (Chavez is strongly against the FTAA), Colombia, and Peru, could therefore be the key to the outcomes of this shuffling process. It seems more likely that such coalitions would be created, at least initially, along two lines: major economies in the hemisphere, and major sectors of interest, e.g. petroleum producers.

On a national level, with the largest market in the world by far, the U.S. should be able to gain highly favorable terms in return for market access. The U.S. would like to keep the rest of the countries from creating a negotiating bloc, which would change its level of leverage, and therefore give concessions to each country. Thus the U.S. has been busy signing free trade agreements with the Caribbean, Central America, the Andean Community,

See the Inter American Development Bank's Intal and the Organization of American States' treaty web sites for a detailed list of existing current agreements and some text. 
and Chile to lock in the playing field for the FTAA negotiations and prevent the emergence of an opposition coalition. Canada has recently signed free trade agreements with Chile (1997) and Costa Rica (2001). Like the U.S., Canada has a strong hand in multilateralism. Like Mexico, Canada and sees an FTAA as one plausible way to reduce dependence on the U.S. Canadian exporters are also keen to gain market access to Latin America. Canada's strategy, like Mexico's, seems to be to attempt to ally itself with some smaller partners to gain leverage. Canada has a strong desire to protect culture and health from U.S. corporate interests in these areas. On the other hand, the close vertical integration that Canada has with the U.S. in key sectors, such as automobiles, means that, like Mexico, its ability to play the field in terms of potential allies is quite circumscribed. As a founding and key member of MERCOSUR, Brazil has a strong interest in creating an anti-U.S. bloc. However, its production profile and interests are different from many of the other nations in the hemisphere, and the U.S. may be able to achieve smaller concessions with key countries on separate side agreements in order to prevent a large alliance. Within MERCosur, Chile as an associate member has left its options open, signing free trade agreements with various regional partners, including Canada, Mexico, Bolivia, outside the region with the European Union, and most recently, with the U.S. However, the recent economic meltdown in Argentina and the devaluation suggest possibilities for a rapprochement between the two giants of the MERCOSUR. Besides NAFTA, Mexico has signed a myriad of bilateral agreements, including ones with the E.U., with Chile, with a number of Central American states, with Group of 3 partners Colombia and Venezuela, and with Bolivia. Mexico has also just reached an economic complementation agreement with MERCOSUR and separately with Brazil.

\section{Treaty Ratification Procedures and Political Opposition to the FTAA}

Treaty ratification procedures are key to international negotiating outcomes because they affect the possible size of the win set. Procedures can also delay and/or open up the treaty in varying degrees to domestic interest groups. In the case of the FTAA, treaty ratification procedures will be particularly important from the point of view of the degree or amount of modifications that could occur, and potentially stall, the treaty's adoption, once a working document is created. Moreover, the executive branch's domestic authority to sign a treaty and implement it could potentially limit the jurisdiction of any international bodies created to arbitrate, mediate, or legislate the treaty.

\section{United States}

The granting of fast-track authority to President Bush in 2002 completely changes the dynamic for trade negotiations in terms of the ability of special interests to affect the outcomes via the U.S. Congress. Fast-track, or trade promotion authority (TPA), allows the 
president to deliver a trade agreement on a pass or fail basis to the Congress, vastly simplifying the negotiating for the U.S., and giving the Executive a huge advantage over the legislature in shaping the agreement and the bargains therein. The TPA of 2002 includes provisions for trade adjustment assistance, and states that agriculture, fishing, textiles, and apparel are sensitive sectors. Aspects involving sensitive sectors require consultation with the Congress, and a report by the U.S. International Trade Commission (USITC) on the possible effects of an agreement. However, the Act also opened the way for duty-free status for apparel from the Andean, Caribbean, and Central American countries (with high caps) and apparel and textiles for African countries. It is important to note that the TPA of 2002 excludes environmental and labor issues. Moreover, it allows for the negotiation of anti-dumping/countervailing duties issues, which have been indirectly offered by the U.S. on the multilateral level in exchange for agricultural concessions by the E.U. It states that NAFTA need not be a model, defusing C.11 objections.

In the U.S., the Executive takes the lead in negotiations via the office of the U.S. Trade Representative (USTR). Informal negotiations also take place with industry associations and, to a lesser extent, with non-governmental organizations, particularly those concerned with environmental and labor standards. A variety of executive agencies also create factfinding missions and reports. Under fast track, most special interest pressure will be on the executive branch in the negotiation stage. A key aspect for the U.S. will be to gauge the extent to which it is willing to concede the special interventions and degrees of autonomy it uses to insulate its economy from trade impacts. These include anti-dumping measures and submissions to international dispute resolution, both of which are recurrent issues in international trade negotiations.

A key legislative election was held in 2002 that could affect the passage of trade negotiations. The Republicans were able to increase their control over the House, but they are in deadlock in the Senate. We should also keep in mind that the more important key to the FTAA is whether Mr. Bush will be re-elected in 2004. The next President's ability to appoint the heads of the Department of Commerce, the Department of State and the USTR will undoubtedly mark the final shape of the FTAA agreement. In 2003, given the precarious state of the U.S. economy, including growing unemployment, several Democratic candidates took strong aim at NAFTA, generally in terms of increasing labor and environmental provisions, though this may be just geared towards the primaries.

Within the executive branch, both ad hoc and formal inter-agency committees, usually led by the USTR, attempt to hammer out differences within the public sector. Members may include Congresspersons and congressional staff. Under the guise of the "official advisory committee system," inter-branch committees and members of interest associations are brought together for consultation. Members are selected for the committees on the basis of qualification, geography, and need. There are 33 committees with approximately 
1,000 members. The committee system is organized into three basic levels: the President's Advisory Committee for Trade Policy and Negotiations (ACTPN); six policy advisory committees; and 26 technical, sectoral and functional advisory committees. Most of the committees are organized along sectoral lines, with industry and agriculture being the primary focal areas. In addition, environmental and consumer organizations are represented in the Trade and Environment Policy Advisory Committee (TEPAC). Trade matters are brought to public attention through public hearings (Huenemann in IDB, 2002). One of the key points of contention here is that environmental and other civil society groups are kept in separate committees. This may improve the quality of the information given by each group, but it also allows the Executive to act as a deliberative body in determining national interests.

\section{Canada}

The Canadian domestic policy environment for international trade is shaped by a number of internal and external factors. Historically, negotiating international trade agreements was a relatively simple process. The Imperial Preference System prior to World War II guaranteed markets for Canadian goods and the post-war General Agreement on Tariffs and Trade (GATT) focused solely on tariff barriers, which were strictly areas of federal jurisdiction. During the past two decades, however, multilateral agreements have increasingly expanded into areas of domestic jurisdiction. Moreover, judicial interpretation of the Constitutional implications of these and previous trade commitments would appear to grant provincial governments increasing legitimacy in international trade matters. Provincial objections have already figured in Kyoto activity.

There are several formal methods of consultation set up by the Canadian government. The Continuing Committee on Trade Negotiations is a forum for federal-provincial consultations. In terms of non-governmental participation, there are the Team Canada Inc Advisory Board and the Special Advisory Committee on International Trade (SAGITs). All members of both the ITAC and the SAGITs are appointed by the Trade Minister. There are 12 SAGITs, with membership from industry associations, environmental groups, and academia, each serving a two-year term. The 12 sAGITs are organized along sectoral lines:

Agriculture, Food and Beverage

Cultural Industries

Environmental

Forest Products

Medical and Health Care Products/Services

Services
Apparel and Footwear

Energy, Chemicals and Plastics

Fish and Sea Products

Information Technologies

Mining, Metals and Minerals

Textiles, Fur and Leather

Members are expected to act with personal independence from their interest group organizations. In addition, there is an Academic Advisory Committee that includes 15 
senior academics from a variety of disciplines. There are a variety of informal consultation efforts, including public hearings, as well (Dymond and Dawson in IDB).

As a parliamentary system, once a treaty is adopted by Canadian negotiators, the passage should be much easier than in the U.S. case. The Prime Minister, by definition controls the Legislature, and in Canada, the Senate is appointed by the P.M. The Canadian Senate operates more as a body for reporting and hearings, rather than as a legislative body. Moreover, the parliamentary system seems to allow for greater control of the bureaucracy and negotiations. However, the outcry over the adoption of the Canada-U.S. TFA treaty has made subsequent Canadian governments much more aware of the long-standing Canadian sensitivity towards U.S. domination. The NAFTA received considerably less opposition in Canada, probably in good part because it was seen as a way to diminish the relative importance of the U.S., and also since Canada-Mexico trade is quite limited. The current make-up of the Canadian House of Commons is dominated by the pro-free trade Liberal Party. Bloc Quebecois (BQ) has historically played an independent role in the Parliament, pushing for greater autonomy for Quebec. In recent years, Quebec has become a successful exporter in a number of industries, such as Bombardier airplanes and HydroQuébec energy, thus, the BQ would most likely be active in these specific sectors in regard to an FTAA. The Progressive Conservatives and Canadian Alliance would potentially make for a formidable opposition party against the dominating Liberals, but historically they have not been able to form any united opposition front. Moreover, both parties are more conservative, with the Alliance making its stronghold in resource-rich and agricultural Western Canada. Thus they are not likely to present any challenge to FTAA passage. The main opposition resides in the NDP, which has had quite limited success (and actually lost seats in the last election) on a national level. Moreover, it appears now that Paul Martin, a Liberal, will be the next Prime Minister, so that the FTAA. Thus, formal differences are likely to center around differences between provincial and sectoral and federal interests. Civil society groups, including unions, NGOs, and other movements are strongly opposed to free trade, but no direct channel of influence. Moreover, it can be argued that an FTAA will actually help to dampen or reduce U.S. domination as well as to help out the developing countries.

\section{Brazil}

Brazil represents the single greatest challenge to U.S. domination of FTAA talks. Besides the large size of the economy, Brazil has a long history of industrial policy and protection of sensitive industries. Indeed, Brazil has had recent disputes with Canada over aircraft production, and with the U.S. over steel and orange juice. Brazil will likely use its strong influence in MERCOSUR to try to create coalitions to block the U.S. Before 1992, the Ministry of Economy, Finance and Planning carried out trade negotiations in cooperation with the Ministry of External Relations (wTO, 2000). Since late 1992, the Ministry of External 
Relations has been responsible for bilateral, regional and multilateral trade negotiations as well as for representing Brazil, and coordinating the country's participation, in international trade-related forums. The Ministry is the only entity with authority to sign international agreements on behalf of the Brazilian Government. The Brazilian Congress then has to approve the treaty by a simple majority.

The Chamber of Foreign Trade (CAMEX) was created in 1995 to formulate and evaluate policies and co-ordinate activities related to foreign trade. It also serves as a forum for discussion between the authorities and sectors directly interested in the conduct of foreign trade policy. The Chamber consists of: the Head of the Presidential Office (Casa Civil) who chairs its meetings, and the Ministers of Agriculture, Finance, External Relations, Planning and Budget, and Industry, Trade and Tourism; the President of the Central Bank also attends the meetings. The Chamber co-ordinates the implementation of its decisions through its Executive Secretariat, but each Ministry remains responsible for matters within its competence. In terms of the FTAA, the public sector's efforts are being coordinated through the National FTAA Secretariat (Secretaria Nacional da ALCA, or SENALCA), under the auspices of the Foreign Ministry. SENALCA holds monthly meetings attended by ministerial representatives, CAMEX, and the Central Bank. Civil society, business, and labor representatives may attend the meetings as guests. The Brazilian Business Coalition (Coalizão Empresarial Brasileira) within the long-standing business association, the CNI, coordinates industry, agriculture, and service interests within the FTAA (de Motta Veiga in IDB).

The election of President Lula has tremendous implications for the future of the FTAA. Lula publicly criticized the FTAA as an example of American domination during the campaign. However, Lula has also agreed to adhere to the rules of the recent $\$ 60$ billion loan from the International Monetary Fund, and has made overtures to the Brazilian military. The Brazilian political system is fragmented structurally by the proportional representation voting system leading to inconsistent party discipline. In the present legislature, the PMDB and PSDB, centrist parties, and the mainstays of the Cardoso Administration, continue to be the most important. Moreover, the PFL, the conservative party with strong roots in the Northeast, occupies a significant presence in both houses, but has had an especially strong effect in the Senate in terms of being able to push for agribusiness. The PT is the only party with clear ideological and consistent organizational traditions, but lacks strength on the national level.

\section{Mexico}

In Mexico, the President has negotiating authority over international trade treaties. Treaties must, therefore, be approved by the Senate. Following such approval, they are considered part of the law of the land. For many years, the PRI (Institutional Revolutionary Party) dominated Mexican politics. Changes of leadership within the party led to the present 
encouraging attitude towards trade liberalization, as highlighted by the NAFTA treaty in 1994. However, at present there is some degree of tension between the new President, Vicente Fox, who is a member of the PAN (National Action Party), and the Mexican Senate, which is split almost evenly between the PAN ( $41 \%$ of seats) and the PRI ( $45 \%$ of seats), and the House, where the PAN has a slight advantage. The PRD made significant gains in the 2003 House elections, but remains a minority party, with less than $20 \%$ of the seats. Moreover, the PRI's ties to NAFTA make an alliance with the PRD, from whom they stole a Presidential election in the 1980s, almost impossible. However, strong elements of nationalism remain within the PRI as well as support within the bureaucracy and stateowned companies, so that they could constrain Fox's negotiating strategy. They have already blocked energy liberalization.

In terms of formal consultation, the Mexican government relies upon the Advisory Council for Trade Negotiations, and the Coordinating Body of Foreign Trade Business Associations (Coordinadora de Organismos Empresariales de Comercio Exterior, or COECE), which represents large businesses with an international orientation. The Advisory Council was set up in 1990 in preparation for the NAFTA negotiations and includes representatives of the private sector, academia, labor and the agricultural sector. COECE has 140 working groups, organized by sector. In addition, informal consultations were held during the NAFTA negotiations with members of civil society. In Mexico, the Ministry of Trade and Industrial Promotion (SECOFI), seems to have the dominant hand in terms of the trade agenda (Alba and Vega in IDB).

As of 2003, there have been a number of official adjustments in order to deal with the painful effects of adjustment to NAFTA. In Sept. 2003, the Mexican authorities discussed the creation of a requirement that all tequila be bottled in Mexico. More than half of Mexico's tequila is exported to the U.S., with total revenues reaching $\$ 764.4$ million in 2002. The possibility looms that the PRD could make a political gain, at least in terms of the upcoming Presidential election in Mexico, as it increased its legislative presence in 2003. If that is the case, there will probably be much more strident anti-free trade discussions in Mexico, linking up with the farmers who have been hurt by NAFTA (see below) and the Zapatistas. The Zapatista movement has always been strongly against NAFTA, as it violates the core principle of regional autonomy. The Zapatista movement, while limited to Mexico's Southern region, undoubtedly reflects polarization with the North, where most maquiladora and other NAFTA effects are found.

\section{Civil Society, Environmental, Labor, Anti-Globalization Movements and Public Opinion}

While the notion of civil society has been bandied about at great length in academic and government circles, in practical terms it seems quite difficult to define. Moreover, by 
definition an unorganized section of society is less likely to come together on a particular issue. Therefore, in speaking of civil society's role in the FTAA, we should really speak of the well-organized lobby groups, rather than the more spontaneous movements interested in globalization. Environmental and labor groups in the U.S. successfully put pressure on President Clinton during the NAFTA treaty ratification process. The result was the side agreements (side payments) which established separate agreements on environmental and labor standards and created the North American Agreement on Environmental Cooperation and the North American Agreement on Labor Cooperation. However, the resulting commissions and policies have remained under fire from activists in the U.S. Since the NAFTA agreement, protests at the meetings of various international forums, such as the World Trade Organization, have witnessed increasing waves of anti-globalization protests and activity, including the World Social Forum. In addition, a number of indigenous groups have opposed the FTAA, including CONAE and the Zapatistas. Yet, by most accounts, the movements remain quite fragmented and diverse. One of the central claims of the movement is that international trade agreements and decisions are neither transparent nor participatory. Pressure from such groups has led governments around the world to take steps, such as increasing participative consultation, to defuse such challenges. Such groups are probably more powerful and better organized in the North than in the South. These groups may affect the ratification process, levels of participation, and particularly public discourse. U.S. and Canadian policymakers may be able use the strength of their domestic groups to leverage concessions. However, in multilateral forums, Southern governments have maintained a strong and consistent position that neither environmental nor labor standards are open for negotiation in trade liberalization talks. Small and medium-sized businesses are particularly concerned about further free trade in Latin America, as they anticipate being swallowed up by U.S. and Canadian multinational companies.

\section{Polls}

Reliable and consistent poll data for the hemisphere do not exist. Trade remains a highly technical issue about which the public seems generally unclear in terms of its general attitude. Still, foreign relations seem to capture a high degree of unhappiness with domestic issues, perhaps a type of scapegoating. According to the University of Maryland Program on International Policy Attitudes (PIPA), since 1997 a plurality of Americans have viewed NAFTA as being favorable, and support has actually increased over time. However, up to $25 \%$ of respondents do not offer an opinion on the subject, and when asked in a particular poll, 51\% said that they "hadn't heard enough to say". ${ }^{2}$ Even amongst the general support,

A poll by La Nación in Argentina in 2001 found that 57\% had not heard of the FTAA; of the 43\% that had, 49\% felt that the FTAA would make little or no difference to Argentina. 
there is consistent poll data from 1996 that Americans had serious reservations about NAFTA, mostly related to the fear that jobs and wages would be lost. There is almost no polling on the FTAA; a 1998 poll found that $67 \%$ of Americans supported free trade with South America.

While there seems to be widespread dissatisfaction with economic conditions, which has spilled over into recent political campaigns, ${ }^{3}$ it is difficult to gauge general public opinion on the FTAA. The recent elections of Lula, Kirchner in Argentina, and Gutierrez in Ecuador (in addition to Chavez's long-standing anti-americanism) are signs that an antineoliberal platform, at least in rhetoric, is becoming increasingly popular. Indeed, a poll run by the Catholic Church and activist groups in Brazil in 2002 showed that out of 10 million Brazilians, 98\% rejected the FTAA. The logical reaction of national governments might be to try to de-link the FTAA from popular dissatisfaction with poor economic conditions by allowing greater access and transparency to civil society groups. At the 2002 Quito Summit, the FTAA Secretariat set up a Committee on Government Representatives on the Participation of Civil Society. However, there is not much evidence of coordinated action, though an open and ongoing invitation to civil society groups was made on March 28, 2003. The Committee gives an e-mail and regular mailing address for written feedback. Clearly, this move will be viewed as insufficient by most of the strongly opposed NGOs. There seems to be little evidence that non-private sector actors are well-organized or are being consulted by governments on a regular basis with regard to the FTAA throughout the hemisphere. Even labor unions show little sign of North-South solidarity (Mejía, 1997). Public opinion matters most when it is aligned with strongly dissonant elements from the elite.

\section{Conclusion on Treaty Ratification Procedures and Domestic Political Opposition}

On the basis of ratification procedures alone, we can make some interesting observations. Ironically, one of Putnam's observations is that if there are heavy domestic constraints, a negotiator at the international level can claim to his colleagues that he has less room for compromise. On the other hand, the size of the win-set in terms of the ease of domestic passage allows negotiators greater leeway in reaching an acceptable agreement. Mexico and the U.S., despite recent arguments against NAFTA, seem to have the largest win-sets. However, Mexico's win-set could change if agricultural issues continue to lead to a coalescence of opposition groups and the PRD candidate wins the Presidential election. In the Canadian case, diverse provincial interests weigh in heavily. In Brazil, there is a strong

A poll conducted among Latin American elites by Zogby International in 2002 found widespread pessimism about the state of their economies (with the notable exception of Chile), and mixed support for integration. The poll found that $54 \%$ favored greater integration with the U.S., while $45 \%$ opposed it. It is interesting to note that a very high percentage, $68 \%$, favored political integration in Latin America following the European example, including $86 \%$ in Venezuela and $74 \%$ in Brazil. The poll also found that $51 \%$ of Mexicans think that NAFTA has hurt the Mexican economy, while $34 \%$ said NAFTA helped it. 
political sentiment against the FTAA. Moreover, the lack of party discipline further complicates any easy ratification. It remains to be seen whether Mexico, Canada and Brazil can use these facts to argue for better terms. Lastly, Mexico and Brazil have highly insulated negotiating teams within the executive branch.

\section{Sensitive National Sectors}

Perhaps one of the most important aspects of the negotiations for free trade is the effect that free trade will have on particularly important economic sectors. International trade theory, going back to the Stolper-Samuelson observations on relative factor prices, has long been concerned with the distributional effects of trade. Free trade should theoretically increase the possibilities for competitively exporting products while damaging industries that are not internationally competitive or that compete with imports. While the net gains may be positive for consumers as a whole, the losses from free trade will be concentrated. Moreover, in political terms, those who benefit from the status quo are naturally better organized than those who might experience potential gains. In both the E.U. and the NAFTA negotiations, sectoral issues were among the most difficult aspects of the negotiations, and gradual or permanent protection for sectors is at the heart of every free trade agreement, reflecting the domestic parameters of each negotiator's win-set.

By value alone, it appears that agriculture, automobiles, fuel (petroleum), electrical machinery, and nuclear reactor materials could be the most contentious products in FTAA negotiations, at least among the principal economies. A Council of the Americas report lists machinery, electrical and electronic machinery, chemicals, and transportation equipment as the top U.S. exports to FTAA countries in 2000. They include apparel, primary food and beverages, and textiles in their estimates of the U.S. export sectors most likely to gain from FTAA implementation. We can summarize the most highly protected national sectors (by rank order of ad valorem tariffs) as follows:

Table 4

\section{Most highly Protected Goods Among Top FTAA Economies}

$\begin{array}{ll}\text { Argentina } & \text { leather, carpets, clothing, arms, toys } \\ \text { Brazil } & \text { vehicles, carpets, shoes, arms, beverages } \\ \text { Canada } & \text { clothing, meat/fish, ships, footwear, cereals, carpets } \\ \text { Mexico } & \text { sugar, meat, tobacco, cereals, dairy, clothing, footwear } \\ \text { U.S. } & \text { tobacco, footwear, dairy, clothing, fruits/vegetables } \\ \text { Venezuela } & \text { meat/fish, carpets, fabric, clothing, fruits/veg.s, iron/steel, grains, beverages, footwear }\end{array}$

Source: Calculated from statistics from the Inter-American Development Bank.

Table 4 indicates that the principle gains to be made, at least tariff-wise, from an FTAA, are in agriculture, apparel and footwear, and automobiles. Previous trade agreements both reinforce this picture and give us a more nuanced view of which sectors will likely be in 
contention. The key common sectors for negotiation in the NAFTA negotiations were agriculture, automobiles, textiles, and, as noted earlier, the perennial issues around investment (Lynch in Kerremans and Switky, 2000). These were distinct from some of the issues that were tackled between the U.S. and Canada in their preceding agreement, where energy, culture, fishing, lumber, and liquor also counted (Kreinin, 2000). The MERCosuR agreement's main sectors of contention were automobiles, textiles, footwear, and sugar and it contains provisions explicitly protecting Argentine and Brazilian interests in this area. Given the Middle East situation and parallel insecurity in the U.S., we can also anticipate that energy will be in focus.

\section{Agriculture}

Agriculture has clearly been the most problematic sector in recent international trade negotiations. As Warley points out, agriculture occupies a special place in many countries' economies. Given the history of uncertainty in agricultural production, and a memory of shortages, food production is often viewed as a vital sector to national security (Cohn in Avery, 1993). In addition, in countries like Japan and Europe, the farm sector is viewed as important for cultural preservation. Given the E.U.'s expansion eastward, agricultural tensions and adjustment within the E.U. itself diminish the possibilities for adjustment to outside producers. While agriculture is not a large employer in the U.S., it is geographically concentrated in the Midwest and Southeast, which gives the lobby strong numerical support in the Senate. The strength of this lobby is clear from the huge agricultural subsidies that were created by the U.S. government in 2002. Agriculture is equally important for similar reasons in the Canadian prairie states. Most developing countries, furthermore, rely heavily on taxes from the export of agricultural produce. Against this backdrop are a variety of weaker pressures for liberalization. These include: the surplus capacity of large producers, including the U.S.; the huge costs of domestic protection and subsidies; and the desire to be somewhat more consistent with the free trade discourse in terms of protectionism against the developing world's principal exports. In addition, in developing countries, important urban food-consuming constituencies exist, and some countries, such as Venezuela, are large food importers.

In terms of agriculture, Mexico should be competitive in terms of tropical agricultural products, like oranges, as well as in selected grains and vegetables, such as tomatoes. On the other hand, other Mexican products, such as wheat and cattle, might be hard-hit by competition from U.S., Canadian, and Argentine exporters. Some Mexican farmers, notably sugar farmers, in 2003 were able to win protective measures from the Mexican government in light of U.S. agricultural subsidies and protectionism. The Fox Administration seemed unsure of a long-term strategy, creating a special tax on fructose imports made from corn syrup in the U.S. This created an artificial shortage of sugar in Mexico, raising the prices 
for consumers and users of sugar, such as domestic producers of soft drinks. This ironically led to Mexico temporarily increasing imports of sugar from the U.S., and taking over bankrupt sugar mills. The Consejo Nacional Agropecuario and the Consejo Agrario Permanente (CAP) have both pushed for a stronger negotiating position on agriculture. The CAP has suggested that protest actions will be forthcoming by year's end if relief does not come soon. Already, agriculture seems to have slowed negotiations on free trade between Mexico and Japan. As a result, the Fox Administration in 2003 has sought to scale back NAFTA agreements on tariff rollbacks in corn and beans. The MERCOSUR countries are major producers of wheat, corn, and meat products. Within the hemisphere, both temperate and tropical agricultural products could create alliances.

\section{Textiles}

Unlike agriculture, progress has been made on a multilateral level to liberalize trade in the sector. The Multi-Fiber Agreement, dating back to the 1960s, had set up a highly protectionist system of tariff and non-tariff barriers to textile imports in the developed world. In the Uruguay Round, for the first time, an agreement was made to phase out protection internationally over a period of 10 years (with quotas set to end in 2004). Recent analyses link the new agreement on textiles to declines in the industry in the U.S. over the last few decades, in sharp contrast to agriculture (Stephan, Oatley, and Harrisan). U.S. concessions to the Caribbean under the CBI program and, more recently, Central America and the Andean Pact, threaten Mexico's maquiladoras. Brazil's potential output of footwear is enormous and will likely be a sticking point for U.S. producers. Mexican textile producers, on the other hand, have been hurt by the rise of illegal imports of cheaper products from China.

\section{Automobiles}

Automobile production is undoubtedly one of the most important, if not the most important industry, in terms of employment, linkages to other industries, and a key producer of strategic technology. The industry can be considered in several ways related to the FTAA. One way is to look at the differences between the production process and the assembly process. In Latin America, countries do not create their own autos. Rather, if they are not imported as finished products, they are either partly produced as part of a global production platform or assembled. In Mexico, automobile production is vertically integrated with large U.S. manufacturers' global production plans. However, a severe slump in the Mexican auto industry, including the closing of a major Volkswagen plant in Puebla has raised doubts about the future health of the industry. This could lead to reluctance to comply with the tariff rollbacks for finished automobiles set up in the NAFTA, as has been the case in agriculture. In Brazil and Argentina, most automobiles are assembled from kits by importing parts from foreign companies, such as Volkswagen. 
Very important implications exist surrounding the differences between these production processes. The first set of implications relate to the rules of origin and local content requirements. Assembling nations would want to have low standards, while verticallyintegrated producers would want lower standards. U.S. manufacturers might generally be seen to favor higher local content requirements because they probably imply a competitive advantage for North American production versus their East Asian and European rivals. On the other hand, if a U.S. manufacturer such as GM is well-entrenched in a local Latin American market, it might actually be against liberalization in order to preserve its local market share. The same kinds of questions will be raised in terms of the export requirements that LACs may have in regard to local production. Of particular importance are the local content and rules of origin provisions that Canada was able to gain through the CanadaU.S. Free Trade Agreement, which were preserved under NAFTA (Lynch in Kerremans and Switcky). Another important aspect of the FTAA negotiations in regard to this sector will be employment and labor standards. North American labor unions will resist any aspect of trade liberalization that could mean a loss of jobs, and push for higher labor standards. It is no surprise that auto unions have been at the forefront of the anti-trade protests in recent years.

\section{Energy}

Given the turmoil in the Middle East and Venezuela, and the energy crisis in California, energy has remained a top priority for U.S. foreign policy. The key issues revolve around U.S. demands for opening up LACs' energy resources to ownership and investment protection by its multinational corporations, which runs up against the nationalistic stance that LACs have traditionally taken towards subsoil rights. Secondarily, U.S. companies would like to gain access to investment in the quickly growing electricity markets in Mexico and Brazil, and to ensure access to electricity supply grids in Canada. The U.S. see its NAFTA partners as potentially important sources of energy for the coming years. As in the NAFTA negotiations, the energy sector is highly sensitive for Mexico, Brazil, and Venezuela. Mexico's electricity sector is also highly limited in terms of foreign investment, although a domestic shortfall is expected. An energy bloc of petroleum producers, including Canada, Mexico, Venezuela, Trinidad, Ecuador, and Colombia, could be the most potent anti-U.S. bloc within an FTAA.

\section{Conclusion- Key sectoral issues}

Given the recent U.S. anti-dumping findings with regard to steel, which affected Brazil, this could be another important issue for discussion. On the export side, the U.S. seems particularly keen to promote high technology, entertainment, financial, and related high revenue services. Therefore, intellectual property rights, and dispute settlement will be important issues. In particular areas, such as telecommunications (Nortel), airplane 
manufacturing (Bombardier); and high technology, Canada will also have strong interests. Like the U.S., Canada will also be anxious to obtain investment security, particularly in the areas where it has a strong position, such as energy development (TransAlberta, QuébecHydro). In terms of sectoral issues, we can use our concept of issue linkage to attempt to anticipate the possible trade-offs and quid pro quos that could be embodied in an agreement. Clearly, in terms of agriculture, Brazil, Argentina and a number of other producers in specific products and countries will be pushing for liberalization, reducing in particular the massive subsidies going to U.S. and Canadian farmers and highly protected products such as sugar and oranges/orange juice. In certain niches, such as possibly wheat and corn, the U.S. will, on the other hand, push for greater liberalization. Agriculture may be the most important sector not only overall, but also in terms of eliminating Latin American negotiating solidarity. The large agricultural producers, Brazil and Argentina, who are pushing strongly for trade liberalization differ from Mexico, whose farm sector is reeling, and will likely seek protection. In fact, open access to the U.S. market might allow Brazil to out-compete Central American and Caribbean agricultural producers as well as U.S. farmers. In terms of heavy industry, the U.S. and Canada will probably seek to halt or condition liberalization, while Mexico and Brazil will push for liberalization. On the other hand, the U.S. and Canada will be heavily in favor of energy liberalization, while the larger LACs countries will seek to protect their state-owned industries. The U.S. will push particularly hard for intellectual property rights and high technology industry liberalization, while other countries will seek to preserve their protection and subsidies of the same. We can predict, therefore, that the main general axis of issue-linkage will be agriculture and heavy industry vs. energy, high technology, and services, including investment.

\section{Investment and other Significant Issues}

Investment is a perennial issue in multilateral trade negotiations, as it reflects the huge disparity of capital accumulation in the North vs. capital shortage in the South. Historically speaking, the history of imperialist investment, and domination of markets by Northern MNCs creates a latent context of conflict between the U.S. and LACs. Many LACs nationalized control of their key natural resource industries, and continue to enshrine the principle of national and public control, including Mexico, Chile, Venezuela, and Brazil. However, the onset of neoliberal policies in the 1990s led to the privatization of many state-owned industries and the reduction of state protection for domestic ownership. The U.S. and Canada would like greater guarantees against unfavorable treatment, particularly for their direct investment, national treatment for foreign firms, and expanded protection against expropriation. In most LACs, foreign companies do not feel confident that the legal system can be a reliable method of contract enforcement, and would like to see an improved tax climate. For some countries, such as Argentina and Chile, there is much less room for 
negotiation, while for other key markets such as Brazil and Venezuela, there is more in terms of leverage with the U.S. The U.S. has seemed willing in principle to concede on frequently-used anti-dumping and countervailing duties at the multi-lateral level, but it would not undermine this effort through a separate FTAA agreement. The U,S. will also probably push for some form of arbitral dispute resolution. As embodied in Chapter 11 of the NAFTA treaty, such measures have created a firestorm of controversy. Investment rights could be a key linkage mechanism for concessions on agriculture from the U.S., but also could prove to be a major stumbling block for an agreement. A variety of other issues, including government subsidies generally, government procurement, transparency, and business facilitation will also form important parts of an FTAA. One of the more interesting issues, beyond the scope of this paper, are the ideas behind an FTAA institutional architecture. The U.S. would likely oppose E.U.-type regional governance, but it might push for more than the MERCOSUR form of informal and state-to-state consultations.

\section{Conclusion}

While acknowledging that the dominating size and diversity of the U.S. economy give it strong leverage in the FTAA negotiations, we have demonstrated in this paper that there are a number of avenues open to the other countries in the hemisphere to attempt to counterbalance this power. LACs can create coalitions, with each other, and with partners such as Canada and the E.U. Secondly, LACs may have power within particular sectors. Through issue-linkage and/or side payments, they can gain concessions in other areas important to them.

We have also demonstrated that domestic, regional, and international political economies are inextricably inter-woven, allowing for not only domestic, but also international coalitions for and against free trade. The real trick of the negotiators will be to create an adequate win-set for the agreement both on the domestic and international fronts. Using issuelinkage and the insulation sometimes provided by differences in domestic ratification procedures and norms, negotiators will seek to maximize national gains while ensuring that the other states have an equal interest in preserving the long-term viability of an agreement. In this sense, the domestic unity of LACs is particularly important to their negotiators. To the extent that domestic consensus on bargaining stances is achieved, the negotiators can best maximize national gains. Moreover, LACs never seem to take advantage of their ability to create coalitions within the domestic economies of partners. For example, it is a mystery why sugar-producing nations in the region fail to create coalitions with U.S. food and candy producers and retailers to fight U.S. protectionism. The important balance for the negotiator will be between inclusion and participation in order to achieve a sustainable consensus, and the ability of the government to provide credible proof of side 
payments and enforcement of agreements on the other. Surprisingly, the transnational and cross-level linkages that one would expect have yet to emerge.

Still, we recognize the staggering complexity of such a bargaining process. Not only is there a wide asymmetry of power variables, including population, economic, territory, and military size, from small Caribbean islands to middle-level countries like Colombia to the larger countries, Brazil, Mexico, and Canada, before we get to the U.S., but a huge number of factors could create potential coalitions, including common sectoral concerns, antiimperialistic political traditions and domestic constituencies, regional rivalries and commonalities, such as Ecuador and Peru (both members of the Andean Pact with a border dispute). Moreover, as Moravscik points out, domestic leaders will likely seek not only to influence their negotiating partners' positions, but also to dynamically shape their domestic win-sets. They may

shape the formal and informal ratification procedure (e.g., voting rules, status of the agreement under separation of powers, party discipline, agenda-setting, issue-linkage) or alter the domestic balance through side-payments, enforcement of party discipline, selective mobilization of political groups, or manipulation of information about the agreement. (More radically, they may seek) to implement a broad program of social or institutional reform (Moravsik in Evans, et al.).

The international bargaining literature also points out that state negotiators have the ultimate tool of vetoing the treaty on the domestic and/or international levels, however the threat must be credible and it is therefore unlikely to be effective if used often. More importantly, on the international level, the value of such a threat will be commensurate with the relative power of the country. That is, the relative value of having that country included in the agreement will determine the level of its veto power. Thus, the more important negotiations during most of the period will be in terms of sectoral and issuelinkage. As collective action and interest group theorists have pointed out, the level of organization, the salience of the issue, and the amount of resources that an interest group controls impacts its power to shape foreign economic policy. Thus, a statesman can use a well-organized private interest in a semi-veto threat, that is, he/she can use the need to placate or feed a powerful domestic interest group whose support is supposedly needed for passage to wring concessions from trading partners. To the extent that those trading partners have a similar situation but face powerful domestic interests in different sectors, issue-linkage and side-payments (partial or full concessions, such as gradual liberalization) can take place. The FTAA, if successful, will have profound effects on the hemisphere and world trade. An accord that reduces U.S. protectionism on agriculture, steel, and other manufactures, could create an important new catalyst for growth and development in the region, as well as pushing the multilateral agenda forward. By creating larger middle class markets in Latin America, the U.S. and the region will gain on both the security and economic fronts. 


\section{Bibliography}

Abreu, Marcelo de Paiva, "The Political Economy of Economic Integration in the Americas: Latin American Interests," texto para discussão núm. 468, Dec., Departmento de Economia, PUC-Rio, 2002.

Allison, Graham T., and Philip Zelikow, Essence of Decision: Explaining the Cuban Missile Crisis, 2nd ed. Reading, MA: Longman, 1999.

Avery, William (editor), World Agriculture and the GATT, Boulder: Lynne Rienner, 1993.

Bennett, Sherry L., and Erick Duchesne, in Bart Kerremans and Bob Switky, The Political Importance of Regional Trading Blocs, Ashgate, 2000, pp. 213-239.

Fred C. Bergsten, "A Renaissance for U.S. Trade Policy?", Foreign Affairs, 81, 6 (Nov/Dec. 2002), pp. 86-99.

Briceño Ruiz, José, “El Modelo TLCAN de Integración y las Negociaciones del ALCA," Problemas del Desarrollo, 32, 126 (julio-septiembre 2001), pp. 35-57.

Cameron, Maxwell A., and Brian W. Tomlin, The Making of NAFTA: How the Deal Was Done, Ithaca: Cornell U. Press, 2000.

Council of the Americas, FTAA: Blueprint for Prosperity: Building on NAFTA's Success, Washington, Sept. 2001.

Evans, Peter B., Harold K. Jacobson, and Robert D. Putnam, Double-Edged Diplomacy: International Bargaining and Domestic Politics, Berkeley: U. of California Press.

Free Trade Agreement of the Americas web-site, http://WWW.FTAA-alca.org/

Grinspun, Ricardo, and Maxwell A. Cameron, "Restructuring North America: The Impact of Unequal Integration," in Theodore Georgakopoulos, Christos C. Paraskevopoulos, and John Smith (editors), Economic Integration between Unequal Partners, Brookfield, VT: Edward Elgar, 1994.

Inter-American Development Bank (IDB), Intal Division, The Trade Policy-Making Process, Level One of the Two Level Game: Country Studies in the Western Hemisphere, Occasional Paper 13, 2002.

Keohane, Robert, International Institutions and State Power, Boulder, Westview, 1989.

Kerremans, Bart and Bob Switky, The Political Importance of Regional Trade Blocs, U.S.: Ashgate, 2000.
Kreinin, Mordechai (editor), Building a Partnership: The Canada-United States Free Trade Agreement, E. Lansing: Michigan State U. Press, 2000.

Mace, Gordon, Louis Belanger et al. (editors) The Americas in Transition: The Contours of Regionalism, Boulder: Lynne Rienner, 1999.

Mayer, Frederick W., Interpreting NAFTA: The Science and Art of Political Analysis, NY: Columbia U. Press, 1998.

Mejía, Alvaro Tirado, Integración y democracia en América Latina y el Caribe, Intal Documento de Divulgación 1, nov. 1997, Washington: InterAmerican Development Bank, 1997.

Poitras, Guy, "Hazards on the Road to 2005: Regionalism as a Contentious Issue in the Americas," conf. paper, International Studies Association annual meeting, Portland, Oregon, Feb. 25-Mar. 1, 2003.

Political Database of the Americas, Georgetown University, source for election statistics.

Putnam, Robert D., "Diplomacy and Domestic Politics: The Logic of Two-Level Games," International Organization 42, 1988, pp. 427 460.

Robert, Maryse, Negotiating NAFTA: Explaining the Outcome in Culture, Textiles, Autos, and Pharmaceuticals, Toronto, U. of Toronto Press, 2000.

Robert, Maryse, and Jose Manuel Salazar-Xirinachs (editors), Toward Free Trade in the Americas, Washington, Organization of American States, 2001.

Stephen, Roland Stephen, Thomas Oatley, and Chris Harrisan, "Three Logics of an International Bargain: Exchange, Domestic Politics, and Coercion in the Uruguay Round," conference paper, American Political Science Convention, Atlanta, Sept. 1, 1999.

Tirado Mejía, Alvaro, Integración y democracia en América Latina y el Caribe, Intal Documento de Divulgación 1, Nov., Washington, InterAmerican Dev. Bank, 1997.

Wise, Carol (editor), The Post-nafta Political Economy: Mexico and the Western Hemisphere, University Park, The Pennsylvania State U. Press, 1998.

World Trade Organization (WTO), Report wT/TPR/s/ 75, Sept. 27, 2000 